\title{
Human Resource Practices in Public Healthcare Sector: A Perceptual Study among Healthcare Professionals
}

\author{
Sumathi G. N.
}

VIT Business School, VIT University, Vellore, India

\begin{tabular}{l}
\hline Article Info \\
\hline Article history: \\
Received Jan 10, 2017 \\
Revised Feb 16, 2017 \\
Accepted Feb 25, 2017 \\
\hline Keyword: \\
Human Resource Practices \\
Healthcare Professionals \\
Primary Health Centres \\
Tamilnadu \\
Public Healthcare Sector \\
\hline
\end{tabular}

\begin{abstract}
The study is aimed to identify various human resource practices in the public healthcare sector and to measure the level of human resource practices. The study adopts the perceptual view of healthcare professionals such as medical officers and staff nurses working in Primary Health Centres of Tamilnadu. A survey using a questionnaire is used to collect data from healthcare professionals. The results indicated that human resource practices such as job autonomy and job security are perceived to be useful and necessary, while training and performance management system are found to provide necessary inputs for carrying job duties and practices such as career growth opportunities and compensation need the attention of the officials of Health and Family Welfare department of Tamilnadu Government for enhancing the utility of these practices.
\end{abstract}

Copyright $(92017$ Institute of Advanced Engineering and Science. All rights reserved.

\section{Corresponding Author:}

Sumathi G. N.,

Associate Professor, VIT Business School,

VIT University, Vellore, India.

Email: sumathi.gn@vit.ac.in

\section{INTRODUCTION}

The report of the National Commission on macroeconomics and health has stated the real need for Human Resource Development policies related to recruitment, promotion and transfer and training so that policies on competencies and career opportunities could counter the demoralization and de-motivation among workforce in healthcare sector. Moreover, the behavior of health care professionals is also seen to be a significant issue in the quality of the service received by the patients and the overall performance of healthcare units. Thus the performance of healthcare unit seems to be largely affected by the issues pertaining to healthcare professionals. With respect to rural health system, delivery of primary healthcare is of prime importance. The Primary Health Centers (PHCs) are the focal points for delivery of health and medical care services in the rural area. Therefore the purpose of this paper is to measure the level of perception of HR practices among medical officers and staff nurses working in Primary Health Centers in Tamilnadu.

The Table 1 shows that countries with most maternal deaths have shown shortage in health work force. Though TamilNadu has 29 health workers per 10,000 population against WHO's definition of 25 workers for 10000 population (National Sample Survey Organization, 2004- 2005), PHCs in TN still report the need for health workers. In PHC, health workers play a crucial in increasing delivery rate from $6.3 \%$ in 2002-03 to $19.68 \%$ in 2008-09 [1].

Table 1. Countries with High Maternal Mortality Shows High Health Workforce Shortage [1]

\begin{tabular}{ccccc}
\hline Country & \multicolumn{2}{c}{ Maternal mortality } & \multicolumn{2}{c}{ Health work force } \\
\hline & Ranking for MDs & Annual MDs deaths (in 1000) & Ranking HWF needed & Estimated shortage (in 1000) \\
India & 1 & 68 & 1 & 515 \\
Pakistan & 3 & 20 & 4 & 202 \\
Uganda & 16 & 5 & 22 & 28 \\
China & 18 & 7 & - & - \\
\hline
\end{tabular}


The Table 2 clearly shows the success of PHCs over the years and emphasizes the importance of carrying out a study among health officials who are behind this success story. Hence a study that measures the perception of human resource management practices among medical officers and staff nurse working in PHCs would be worthy at this moment. Moreover, there is no systematic study so far carried to understand the perception of HR practices among medical officers and staff nurses with special reference to PHCs. Although there are numerous studies on human resource practices, there are very less studies that measures human resource practices in healthcare sector, particularly from employee perspective.

Table 2. Year Wise Performance of PHCs in Tamil Nadu

\begin{tabular}{cccc}
\hline Year wise performance of PHC & 2007-2008 & 2008- 2009 & 2009- 2010 Upto Dec.2009 \\
\hline Average no. of Out-Patients per PHC per day & 134 & 140 & 141 \\
Average no. of In-Patients per PHC per month & 37 & 45 & 53 \\
Percentage of deliveries in PHC per month & 9 & 15 & 16 \\
\hline
\end{tabular}

Source: www.tnhealth.org

Research studies have clearly shown the positive influence of human resource (HR) practices in enhancing organizational performance [2]-[4] and improving employee attitudes like employee commitment, job satisfaction, perceived organizational support, employee performance and employee motivation [5]. Moreover, the employees' attitudes towards HR practices are seen as drivers of discretionary behavior [6]. Especially in a service sector, the behavior of healthcare professionals (doctors and nurses) towards the patients relies on professionals' attitude towards their work. HR practices are the communication from the organization and they elicit certain kind of behavior among employees. With the growing importance of meeting the Millennium Development Goals [7],[8], the Indian public health care sector is showing greater interest in improving health care indicators. The public health system is facing challenges like large scale absenteeism, absence of performance based monitoring, inequalities in available skills, movement of health workers from public to private, public outcry of poor performance of health personnel, negative attitude and low motivation of health workers and limited opportunities for career advancement. At this juncture, it is important to look into the human resource policies in the public healthcare sector for retaining the health workforce and to provide quality health services. The purpose of this study is to identify various human resource practices in public healthcare sector and to measure the level of human resource practices through the perceptual study among medical officers and staff nurses.

\section{LITERATURE REVIEW}

HRM has been defined as a term to represent that part of organisation's activities concerned with the recruitment, development and management of its employees [9]. When the level of perception of HRM practices is high, the employees score high on work-related attitudes [10]. Moreover the HRM practices have shown to influence employee attitudes like job satisfaction and organizational commitment [11]. HR practices include training, pay and promotion, opportunities for recognition, etc. Relying on social exchange theory and the norm of reciprocity, HR practices are proposed to shape workforce attitudes by modeling employees' perceptions about the organization. Career growth prospects are found be a significant positive predictor of overall organizational citizenship behaviour [12]. In retail setting, professional development of customer contact employees is found to be a predictor of organizational citizenship behaviour [13]. The incentive programs are aimed to increase specific behavior in employees [14]. Pay satisfaction of public school teachers is found to be positively related to district level academic performance and negatively related to teacher's intention to quit [15]. Employee perception of rewards equity and recognition is found to show direct effect on prosocial organizational behaviour [16]. Employees of Fortune Global 100 Company in Korea showed greater in role performance, when they perceived higher job autonomy. It is also found that the job autonomy predicted in-role performance [17]. Government administrative employees who perceived higher job autonomy are rated above average by their supervisors in terms of contextual performance [18]. But the results of Chiu and Chen's study [19], did not show relationship between job autonomy and organizational citizenship behavior. Moreover, intrinsic motivation is found to fully mediate the relationship between job autonomy and job performance [20]. Pay satisfaction of public school teachers is found to be positively related to district level academic performance and negatively related to teacher's intention to quit [15].

According to social exchange theory, employees seek and maintain relationship that promise for a high reward for their contribution. Employees show discretionary effort, when they are satisfied with the rewards like promotion. They show attachment towards their organisation, when they believe that they are

IJPHS Vol. 6, No. 1, March 2017 : 51 - 56 
being treated as resources to be developed [21]. An investment in general development is found to be positively associated with commitment, and those who are more satisfied with opportunities to enhance their employability in their current firms, are much more committed than those who are not satisfied [22]. If the employee's acceptance on the existence of practices like selection, pay for performance is high, the future performance of the firm is expected to be high with the mediating effect of organizational commitment (OC) [3] Studies on commitment clearly showed that the committed employees are more likely to remain in the organisation and work towards the organisation goals [23]. The employee satisfaction with individual development mediated the relationship between employee development oriented HRM practices (like training) and OC [24]. The overall perception about the effectiveness of HRM practices positively influences OC [25]. The HRM practices like performance appraisal, compensation, and career development have shown a positive and direct influence on affective commitment among IT employees [26]. HRM practices like consultation in posting, role of training subordinates, importance to job security showing a positive relation in bringing OC [27]. The opportunity for promotions has shown a positive influence on professional commitment [28]. The investment in the career development of health officials would retain continued interest in the profession. Participation in technical decisions is a significant predictor of professional commitment [29]. Rewards and recognition based on performance would create a competitive climate among health officials that would prove their involvement in the profession. Supervision would help health officials to correct their mistakes and learn better ways of improving their performance. Higher the job security, health officials do not have to think about the risk of losing jobs and could concentrate on clinical activities). The study of Maheswari et al. [27] conducted among Gujarat state health officials found that medical officers show a greater professional commitment than their commitment towards PHCs.

As per Herzberg [30], the motivating factors like achievement, recognition in the job, the job performed, responsibility, promotion and the factors related to job itself result in job satisfaction. The HRM practices like training, pay practices have shown positive significant effect on overall job satisfaction [31]. Those employees, who attach the possibility of getting high pay for the job they perform, show higher levels of job satisfaction [32]. In addition to pay, employees opine that fringe benefits lead to higher levels of job satisfaction especially the availability of pension influences the job satisfaction of employees [33]. Employees' perception of empowerment influences job satisfaction [34]. From the above discussion, it is clear that human resource practices are necessary to achieve positive organizational outcomes and individual outcomes.

\section{RESEARCH METHODOLOGY}

The population for the study includes all medical officers and staff nurses working in 1539 PHCs of TamilNadu [35]. The sample includes Medical Officers (MO) and Staff Nurses (SN) working in Vellore Health Unit District (HUD), Saidapet HUD, Kanchipuram HUD and Tiruvannamalai HUD. These four HUDs have been selected because the researcher has been permitted to undertake survey in those PHCs. Under each HUD, PHCs with a minimum of two MOs and three SNs are selected for the present study. The medical officers and staff nurses within the selected PHCs are selected based on their availability in the PHC. This study considers a sample size of 323 with 130 MOs and 193 SNs. Questionnaire is used to collect primary data from MOs and SNs using survey method. Preliminary interviews have been conducted with medical officers, staff nurses and other PHC staffs to understand the functioning of PHCs and human resource practices. Items to measure training, career growth opportunities, job security, compensation and job autonomy are adapted from Maheswari et al. [27]. Items to measure performance management system are adapted from Brisnav and Rangnekar [36]. Some of the sample items are to measure human resource practices are: "Training provided to me meets my job requirements, Amount of training given to me satisfactory, Group performance is given more importance than individual performance, there is no partiality while making promotional decisions based on seniority, I can pause in work whenever I want".

All the items are measured on a five- point Likert scale. The sample size includes 323 healthcare professionals including 130 medical officers $($ male $=79$; female $=51$ )with an average age of 34 years, work experience in the current PHC of 2.7 yrs and total work experience of 5.8 yrs and 193 staff nurses with an average age of $25 \mathrm{yrs}$, work experience in this PHC of 2.1 yrs and total work experience of 2.7 yrs. The study includes 73 PHCs comprising of 13 block level PHCs, 64 additional PHCs, 6 blocks \& upgraded PHC and 3 additional \& upgraded PHCs from four different health unit districts of 25 from Vellore health unit district, 18 from Saidapet health unit district, 14 from Kanchipuram health unit district and 29 from Tiruvannamalai health unit district. In order to identify various human resource practices, exploratory factor analysis has been carried. The level of identified human resource practices are measured by carrying out descriptive analysis. The SPSS of version 20 is used to carry out the analysis. 


\section{DATA ANALYSIS}

The first step is to undergo exploratory factor analysis to understand the grouping of HR practices in the study context. Exploratory factor analysis is used to assess the unidimensionality and validity of the constructs. The factor loading above 0.6 is considered in this study. The items to measure the independent variables HR practices have underwent varimax rotation. The items have loaded highly onto a single factor and have loaded less on other factors indicating unidimensionality and convergent validity with the variance extraction of $74.39 \%$. The items of HR practices loaded on six factors from Table 3. Cronbach alpha is used to access the scale reliabilities and the alpha values ranged from 0.70 to 0.91 meeting the standards inTable 4 .

Table 3. Results of EFA on HR Practices

\begin{tabular}{|c|c|c|c|c|c|c|}
\hline \begin{tabular}{c} 
Items\} $\\
{\text { Loading }}$ & $\begin{array}{c}\text { Job } \\
\text { autonomy }\end{array}$ & Compensation & $\begin{array}{l}\text { Career growth } \\
\text { opportunities }\end{array}$ & $\begin{array}{c}\text { Job } \\
\text { security }\end{array}$ & $\begin{array}{c}\text { Performance } \\
\text { management system }\end{array}$ & Training \\
\hline $\mathrm{T} 1$ & -.032 & .085 & .069 & -.001 & .010 & .855 \\
\hline $\mathrm{T} 2$ & -.058 & .036 & .071 & .017 & .180 & .855 \\
\hline $\mathrm{T} 3$ & .099 & .037 & .145 & .140 & .322 & .512 \\
\hline P1 & .166 & -.002 & .173 & .143 & .793 & .158 \\
\hline $\mathrm{P} 2$ & .077 & .068 & .152 & .213 & .761 & .109 \\
\hline $\mathrm{P} 3$ & .031 & .310 & .094 & .009 & 611 & .127 \\
\hline $\mathrm{Ca} 3$ & .075 & .206 & .791 & .001 & .243 & .107 \\
\hline $\mathrm{Ca} 4$ & .115 & .133 & .885 & .060 & .178 & .099 \\
\hline $\mathrm{Ca} 5$ & .065 & .166 & .850 & .069 & .043 & .076 \\
\hline JS1 & .232 & .076 & .136 & .779 & .086 & .045 \\
\hline JS2 & .244 & .086 & .056 & .830 & .086 & .168 \\
\hline JS3 & .053 & .163 & -.050 & .691 & .178 & -.064 \\
\hline $\mathrm{C} 1$ & .026 & .882 & .138 & .160 & .117 & .070 \\
\hline $\mathrm{C} 2$ & .039 & .922 & .145 & .110 & .112 & .065 \\
\hline C3 & .098 & .865 & .218 & .085 & .083 & .033 \\
\hline Jo3 & .874 & .006 & .086 & .172 & .067 & .012 \\
\hline Jo4 & .918 & .072 & .090 & .176 & .128 & .005 \\
\hline Jo5 & .915 & .085 & .074 & .159 & .086 & -.041 \\
\hline
\end{tabular}
\end{tabular}

The Table 4 indicates the results of factor analysis. All the items to measure training are loaded into single factor, similarly all the items of respective variable loaded into corresponding factors. Moreover all the factor loadings are above 0.6 .

Table 4. Descriptive Statistics, Reliability Values and Correlation among Study Variables

\begin{tabular}{|c|c|c|c|c|c|c|c|c|c|}
\hline \multirow{2}{*}{ Construct } & \multirow{2}{*}{$\mathrm{CA}$} & \multirow{2}{*}{ Mean } & \multirow{2}{*}{ S.D. } & \multicolumn{6}{|c|}{ Correlation values } \\
\hline & & & & TRG & PMS & CGO & JS & $\mathrm{COM}$ & JA \\
\hline TRG & 0.66 & 3.81 & 0.41 & 1 & & & & & \\
\hline PMS & 0.69 & 3.61 & 0.61 & $0.40 * *$ & 1 & & & & \\
\hline CGO & 0.86 & 2.13 & 0.79 & $0.28 * *$ & $0.40 * *$ & 1 & & & \\
\hline JS & 0.70 & 4.43 & 0.50 & $0.17 * *$ & $0.35^{* *}$ & $0.18 * *$ & 1 & & \\
\hline $\mathrm{COM}$ & 0.91 & 2.17 & 0.96 & $0.18 * *$ & $0.32 * *$ & $0.34 * *$ & $0.29 * *$ & 1 & \\
\hline JA & 0.92 & 4.58 & 0.49 & 0.06 & $0.26^{* *}$ & $0.22 * *$ & $0.40 * *$ & $0.16^{* *}$ & 1 \\
\hline
\end{tabular}

$* \mathrm{p}<0.05, * * \mathrm{p}<0.01$ (two tailed) CA- Cronbach Alpha; S.D.- Standard Deviation; TRG- Training; PMS- Performance management system; CGO- Career growth opportunities; JS- Job security; COM- Compensation; JA- Job autonomy

The first column of the Table 4 indicates the Cronbach alpha values of the constructs. The reliability values of the constructs ranged from 0.66 to 0.92 . The second column indicates the mean values of the constructs. The health care professionals have reported low on career growth opportunities and on compensation practices, while rated high on job autonomy and job security practices. This implies that greater job autonomy is one of the main reasons for the better functioning of primary health centres followed by high job security which is a key factor for healthcare professionals to join the public set up. The mean values of training and performance management system are slightly above average. The healthcare professionals undergo continuous training and moreover Tamilnadu health system project implements training plan for all PHC staffs. Therefore healthcare professionals would consider training as a routine activity. With respect to performance management system, there is no stringent system to measure healthcare professionals' performance although performance audits are conducted to verify various records maintained at PHC level. The healthcare professionals get feedback about their performance from their supervisors while on-the- job and during monthly meetings.

The relationship among the human resource practices are investigated using Pearson Product Moment Correlation Coefficient. As shown in the Table 4, the HR practices are positively correlated with each other. From the bivariate correlation table, the correlation values among the human resource practices range 0.06 to 0.40 . 


\section{DISCUSSION OF FINDINGS}

The study attempted to identify various human resource practices and the level of human resource practices among healthcare professionals. This study contributes to the literature on human resource practices. The results of the study indicated that the healthcare professionals' perceptions about job autonomy and job security are found to be high. Moreover job autonomy is necessary for healthcare professionals to provide quality service to patients. One of the reasons for healthcare professionals to choose public set up is job security. Therefore, it is obvious that they would involve in activities that would benefit their organization. High level of job autonomy in PHCs give a feeling of pride and happiness to healthcare professionals, that meets the higher level individual needs according to Herzberg two factor theory. Although there is no formal system of managing healthcare professionals' performance, the supervisor provides feedback to the healthcare professionals. For staff nurses, the in-charge medical officer acts as immediate supervisor and for medical officers, the block medical officer acts as immediate supervisor. Based on the nature of relationship with the supervisor, the healthcare professionals would enjoy job autonomy.

The results of the study establish the psychological process of the healthcare professionals. They provide important implications to the Health and Welfare department of Tamilnadu. The job autonomy has been identified as an important HR practice that is prevailing in the public health set up. In the health care context, health care professionals with high level of job autonomy are able to carry out their job well and also extend an extra mile to provide additional services to other individuals in the work place and to the patients. Job security has seen to be attractive among healthcare professionals that they remain with the organization.

\section{CONCLUSION}

The results of the study indicated that the human resource practices are varying in their level as per the perception of healthcare professionals. Job autonomy and job security are perceived to be highly necessary among the healthcare professionals. Training and performance management system are perceived to provide necessary skills and knowledge inputs for carryibg out job duties of primary health centres. Finally, the growth opportunities and compensation are those practices that require attention from the higher officials for enhancing the utility of those practices. The study has focused to measure the perception of HR practices among medical officers and staff nurses working at the tertiary level of public health system. Although there would be slight variations in HR policies across different levels of public health system, health care professionals' perception of HR practices could be measured and compared at different levels.

\section{ACKNOWLEDGEMENTS} Tamil Nadu.

We thank the Government of Tamil Nadu for permitting us to conduct a survey in the districts of

\section{REFERENCES}

[1] P. Padmanabhan, "Health and Human Resources: priorities in India," Oral presentation in International Conference on Health systems strengthening, 2010.

[2] A. P. Bartel, "Human resource management and organisational performance evidence from retail banking," Industrial and Labor Relations Review, vol. 57, pp. 181- 203, 2004.

[3] P. M. Wright, et al., "The impact of HR practices on the performance of business units," Human Resource Management Journal, vol. 13, pp. 21-36, 2003.

[4] M. A. Huselid, "The impact of human resource management practices on turnover, productivity, and corporate financial performance," Academy of Management Journal, vol. 38, pp. 635-672, 1995.

[5] G. N. Sumathi, et al., "Impact of work experiences on perceived organizational support: a study among healthcare professionals," AI \& Society, vol/issue: 30(2), pp. 261-270, 2015.

[6] J. Purcell, et al., "Understanding the People and Performance Link: Unlocking the Black Box," Chartered Institute of Personnel and Development, London, 2003.

[7] S. P. Agarwal, "Towards achieving millennium developmental goals in the health sector in India," Indian Academy of Clinical Medicine, vol. 6, pp. 268- 274, 2005.

[8] MDGR, "The Millenium Development Goals Report," Retrieved from http://www.beta.undp.org/content/ dam/undp/library/MDG/english/MDG_Report_2011_EN.pdf on 09.09.2011.

[9] S. J. Wood and T. D. Wall, "Human resource management and business performance in P.B. Warr, eds, Psychology at work," Harmonsworth, Penguin, 2002.

[10] D. Guest, "Human resource management, corporate performance and employee well- being: building the worker into HRM," The Journal of Industrial Relations, vol. 44, pp. 335- 338, 2002.

[11] F. Edgar and A. Geare, "HRM practice and employee attitudes: different measures-different results," Personnel Review, vol. 3, pp. $534-549,2005$. 
[12] D. Okurame, "Impact of career growth prospects and formal mentoring on organizational citizenship behaviour," Leadership and Organizational Development Journal, vol. 33, pp. 66-85, 2012.

[13] A. L. Ackfeldt and L. V. Coote, "A study of organizational citizenship behaviors in a retail setting," Journal of Business Research, vol. 58, pp. 151-159, 2005.

[14] S. J. Peterson and F. Luthans, "The impact of financial and non- financial incentives on business-unit outcomes over time," Journal of Applied Psychology, vol. 91, pp. 156-165, 2006.

[15] S. C. Currall, et al., "Pay satisfaction and organizational outcomes," Personnel Psychology, vol. 58, pp. 613-640, 2005.

[16] B. L. McNeely and B. M. Meglino, "The role of dispositional and situational antecedents in pro-social organizational behavior: An examination of the intended beneficiaries of pro-social behaviour," Journal of Applied Psychology, vol. 79, pp. 836-844, 1994.

[17] F. P. Morgeson, et al., "The importance of job autonomy, cognitive ability and job related skill for predicting role breadth and job performance," Journal of Applied Psychology, vol. 90, pp. 399-406, 2005.

[18] I. R. Gellatly and P. G. Irving, "Personality, autonomy and contextual performance of managers," Human Performance, vol. 14, pp. 231-245, 2001.

[19] S. F. Chiu and H. L. Chen, "Relationship between job characteristics and organizational citizenship behavior: the meditational role of job satisfaction," Social Behavior and Personality: An International Journal, vol. 33, pp. 523540, 2005.

[20] B. K. Joo, et al., "Investigating the influences of core self-evaluations, job autonomy and intrinsic motivation on inrole job performance," Human Resource Development Quarterly, vol. 21, pp. 353-371, 2010.

[21] K. Gaertner and S. Nollen, "Career experience, perceptions of employment practices, and psychological commitment to the organization," Human Relations, vol. 42, pp. 975-991, 1989.

[22] C. D. Galunic and E. Anderson, "From security to mobility: generalized investments in human capital and agent commitment," Organization Science, vol. 11, pp. 1-20, 2000.

[23] D. W. Yousef, "Organisational commitment: a mediator of the relationships of leadership behaviour with job satisfaction and performance in a non-western country," Journal of Managerial Psychology, vol. 15, pp. 6-24, 2000.

[24] K. J. Zaleska and L. M. Menezes, "Human resources development practices and their association with employee attitudes: between traditional and new careers," Human Relations, vol. 60, pp. 987-1018, 2007.

[25] E. Chang, "Employees' overall perception of HRM effectiveness," Human Relations, vol. 58, pp. 523-544, 2005.

[26] A. K. Paul and R. N. Anantharaman, "Impact of people management practices on organizational performance: an analysis of a causal model," The International Journal of Human Resource Management, vol. 14, pp. 46-1266, 2003.

[27] S. Maheswari, et al., "Commitment among state health officials and its implications for health sector reforms: lessons from Gujarat," Indian Journal of Medical Research, vol. 127, pp. 148- 153, 2008.

[28] I. W. G. Kwon and D. W. Banks, "Factors related to the organisational and professional commitment of internal auditors," Managerial Auditing Journal, vol. 19, pp. 606-622, 2004.

[29] A. Somech and R. Bogler, "Antecedents and consequences of teachers organizational and professional commitment," Educational Administrative Quarterly, vol. 38, pp. 555-557, 2002.

[30] F. Herzberg, "One more time: how do you motivate employees?," Harvard Business Review, vol. 46, pp. 53-62, 1969.

[31] A. I. Petrescu and R. Simmons, "Human resource management practices and workers' job satisfaction," International Journal of Manpower, vol. 29, pp. 651-667, 2008.

[32] S. J. Linz, "Job satisfaction among Russian workers," International Journal of Manpower, vol. 24, pp. 626-652, 2003.

[33] B. Artz, "Fringe benefits and job satisfaction," International Journal of Manpower, vol. 31, pp. 626-644, 2010.

[34] N. Karia and A. Z. Ahmad, "Quality practices that pay: empowerment and teamwork," Malaysian Management Review, vol. 35, pp. 66-76, 2000.

[35] GOTN, "Policy note on health and family welfare, Government of Tamil Nadu," 2010. Retrieved from http://www.tn.gov.in/policynotes/pdf/health_family_welfare.pdf.

[36] M. Brisnav and S. Rangnekar, "Enhancing employee human capital benefits through knowledge management: a conceptual model," Global Journal of e-Business \& Knowledge management, vol. 5, pp. 20-26, 2009.

\section{BIOGRAPHY OF AUTHOR}

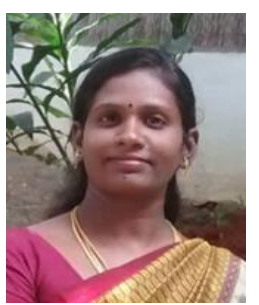

Sumathi G N is an Associate Professor at VIT Business School in VIT University. Her publications include research articles on human resource management practices, employeeorganization relationship, work-life balance and public health. Her research focuses on organizational practices that would help employees to achieve work-life balance and greater performance. She has 6 years' experience in teaching management and engineering students. Before joining VIT, she worked at Anna University, Chennai. She has earned $\mathrm{PhD}$ in Management from IIT Madras and also earned MBA from School of Management, Pondicherry University and Bachelors in Textile Technology from A.C. Tech, Anna University. 